veloped an interest in the Trubetskoi equestrian statue of Alexander III and in the Cathedral of Christ the Savior in Moscow, which Stalin had had destroyed and which was recently reconstructed and reopened; Carlisle was invited to attend these opening ceremonies.

His principal articles included "Uzbekistan and Uzbeks," in Z. Katz, R. Rogers, and F. Harned, eds., Handbook of Major Soviet Nationalities (1975); "Modernization, Generations, and the Uzbek Intelligentsia," in P. Cocks, R. Daniels, and N. Heer, eds., The Dynamics of Soviet Politics (1976); "Power and Policy in Uzbekistan: From Stalin to Gorbachev," in William Fierman, ed., Soviet Central Asia: The Failed Transformation (1991); "Soviet Uzbekistan: State and Nation in Historical Perspective," in Beatrice F. Manz, ed., Central Asia in Historical Perspective (1994); "Islam Karimov and Uzbekistan: Back to the Future?" in T. J. Colton and R. C. Tucker, eds., Patterns in Post-Soviet Leadership (1995). Carlisle's book (co-authored with Leonid Levitin) entitled Islam Karimov-President of New Uzbekistan (1995) was published in English, Russian, German, and Uzbek editions. Shortly before his death, Carlisle had completed the manuscript of his planned pièce de résistance entitled Uzbekistan under Russian Rule, which had already been accepted for publication.

RAYMOND T. MCNALIY

Boston College

December 1997

\title{
George Basilus Tokmakoff, 1928-1997
}

George Basilus Tokmakoff, professor emeritus of Russian history at California State University, Sacramento, passed away on 15 November 1997 at the age of sixty-nine. Born in Tientsin, China, of Russian immigrant parents, Tokmakoff emigrated to the United States in 1947. He earned his undergraduate degrees at the University of Washington and his doctorate at the University of London's School of Slavonic and East European Studies. Tokmakoff wrote P. A. Stolypin and the Third Duma: An Appraisal of the Three Major Issues (1981), in addition to several articles and book reviews. He was a frequent contributor to international panels dealing with Stolypin, the agrarian issue, and the reign of Nicholas II. In 1991, Tokmakoff retired from California State University, Sacramento, but he was actively involved in a definitive work on the reign of Nicholas II at his death. He will be sorely missed by thousands of students; friends across the world; his children, Andrei and Larisa; and his granddaughter, Lena.

RichaRd D. Hughrs

California State University, Sacramento December 1997 